\title{
簡易な現地浸透試験に基づく 地盤の浸透能力の評価方法について ESTIMATION METHOD FOR INFILTRATION CAPACITY OF SOILS BASED ON SIMPLIFIED IN-SITU PERMEABILITY TESTS
}

\author{
岡泰道 ${ }^{1} \cdot$ 松井準 $^{2}$ \\ Yasumiti OKA and Jun MATSUI

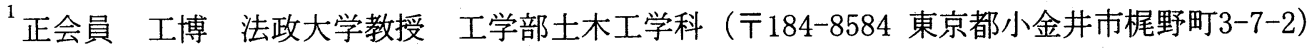 \\ ${ }^{2}$ 学生会員 法政大学大学院 工学研究科（†184-8584 東京都小金井市梶野町3-7-2）
}

\begin{abstract}
Permeability tests have been widely used to estimate infiltration capacity of field soils. This study aims to discuss the applicability of borehole falling head tests(FHT) to the evaluation of saturated hydraulic conductivity $\left(\mathrm{k}_{0}\right)$ of the soils under dry conditions. Parameters relating to soil properties are determined by preliminary analyses with the test data obtained in Tsurumi River Basin. Also, the validity of Glover's equation is examined, based on the formula proposed by ARSIT. In addition, an empirical formula specifying the initial condition of the surface soil layer is introduced on the basis of the field data observed by tensiometers, and its parameters are classified according to the season and soil depth. As a result, $\mathrm{k}_{0}$ values evaluated from FHT carried out for the dry Kanto loam soils are in good agreement with the values obtained by constant head tests and FHT under wet conditions.
\end{abstract}

Key Words : infiltration capacity, hydraulic conductivity, borehole test, falling head test specific infiltration

\section{1.はじめに}

都市域の流出抑制を目的とした雨水浸透施設を設計す る場合には、表層地盤の浸透能力の評価が必要となる。 このための手法については多くの研究が行われ、その一 部はすでに雨水浸透施設技術指針（案） 11 の中に盛り込 まれている。同指針では現地浸透試験法の一つとして定 水位ボアホール浸透試験結果を用いた評価方法が示され ているが、孔内水位を一定に保つ定水位法に基づいてい るため、試験に多くの水量と時間を要し、試験によって は大掛かりな投資を必要とする。したがって、実施の簡 易な変水位法が確立されれば、施設の設計上、きわめて 有利となることが期待される。

現地変水位試験については従来様々な試験法や評価式 が提案されてきた ${ }^{2)}$ ，3。しかし、ボアホール変水位試 験については提案式の適用条件、精度等が十分に明確で ないものが多く、また、結果から直接得られる物理量が 透水性を示す絶対的な尺度でないこと、ならびに初期の 表層土壌水分分布が試験結果に大きな影響を及ぼしてし まうことなどから、評価手法の確立がなされていないの
が現状である。こうした中で、近年、評価のある程度確 立されている定水位試験の情報を基に、変水位の定量化 の試みがいくつかなされるようになってきた ${ }^{4)}$ ，5）。

本研究では、これらの研究も踏まえ、現地地盤におい て実施した定水位、変水位浸透試験結果に基づき、数值 シミュレーションを含めた解析を行うことにより、指針 との対応づけを考慮した変水位浸透試験の評価手法の確 立を目的とした。

\section{2. 現地浸透試験}

筆者らは、都立小金井公園ならびに鶴見川流域を対象 として、ボアホール浸透試験を行ってきた。この試験は ポストホールオーガによる掘削孔(直径17～21cm)に注水 を行い、図-1の装置を用いて現地地盤の浸透量あるい は孔内水位の時間的な変化を計測するものである。試験 の種類を表- 1 に示すが、浸透面が乾燥状態と推定され る定水位試験実施前の変水位試験（試験(3)）、定水位試 験（試験(1)）、湿潤状態と推定される定水位試験後の変 水位試験（試験(2)）の3つに大別できる。解析手順とし 


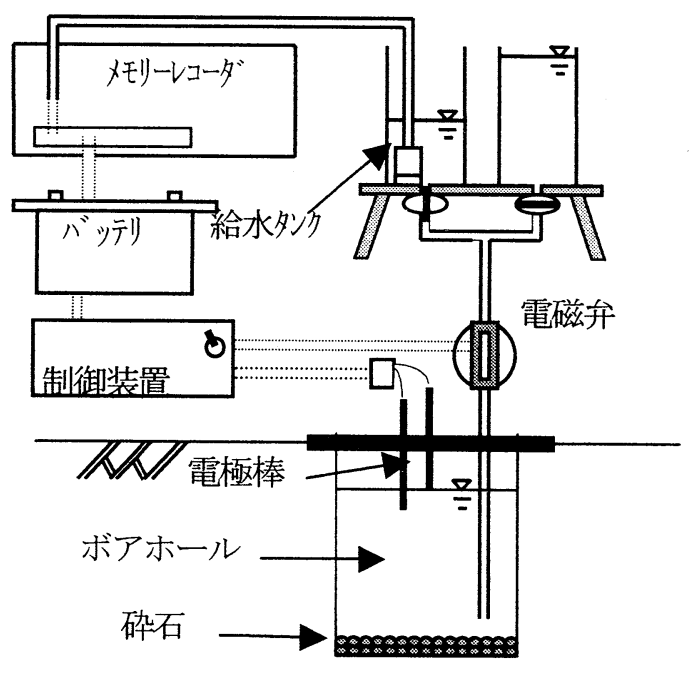

図-1＼cjkstart現地浸透訊験装置
表-1 解析に用いた現地浸透試験結果の内訳

\begin{tabular}{|c|c|c|c|c|}
\hline 対象地域 & $\begin{array}{l}\text { 土質 } \\
\text { 分類 }\end{array}$ & $\begin{array}{r}\text { 変水位 } \\
\text { (定水位 } \\
\text { 前) }\end{array}$ & 定水位 & $\begin{array}{l}\text { 変水位 } \\
\text { (定水位 } \\
\text { 後) }\end{array}$ \\
\hline $\begin{array}{l}\text { 小金井 } \\
\text { 公園内 }\end{array}$ & \multirow{2}{*}{$\begin{array}{l}\text { 関東 } \\
\text { ローム }\end{array}$} & 10地点 & $\begin{array}{c}10 \\
\text { 地点 }\end{array}$ & 10地点 \\
\hline 鶴見川流域 & & $\begin{array}{c}\text { データ } \\
\text { なし }\end{array}$ & $\begin{array}{c}6 \\
\text { 地点 }\end{array}$ & 6地点 \\
\hline
\end{tabular}

表-2 変水位試験の解析に用いる計算条件

\begin{tabular}{|c|c|c|c|c|c|}
\hline \multirow{2}{*}{$\begin{array}{l}\text { 表層 } \\
\text { 状態 }\end{array}$} & \multicolumn{4}{|c|}{ 土堙パラメータ } & \multirow{2}{*}{$\begin{array}{l}\text { 初期条件 } \\
\text { (吸引圧分 } \\
\text { 布) }\end{array}$} \\
\hline & $\theta_{0}$ & $\theta_{\mathrm{r}}$ & 定数 $\alpha$ & 定数 $\beta$ & \\
\hline 湿潤 & \multirow{2}{*}{0.75} & \multirow{2}{*}{0.45} & \multirow{2}{*}{4000} & \multirow{2}{*}{5} & $\begin{array}{c}-60 \mathrm{cmH}_{2} \mathrm{O} \\
(\text { 一様分布) }\end{array}$ \\
\hline 乾燥 & & & & & $\begin{array}{c}\text { 乾燥履歴に } \\
\text { より異なる }\end{array}$ \\
\hline
\end{tabular}

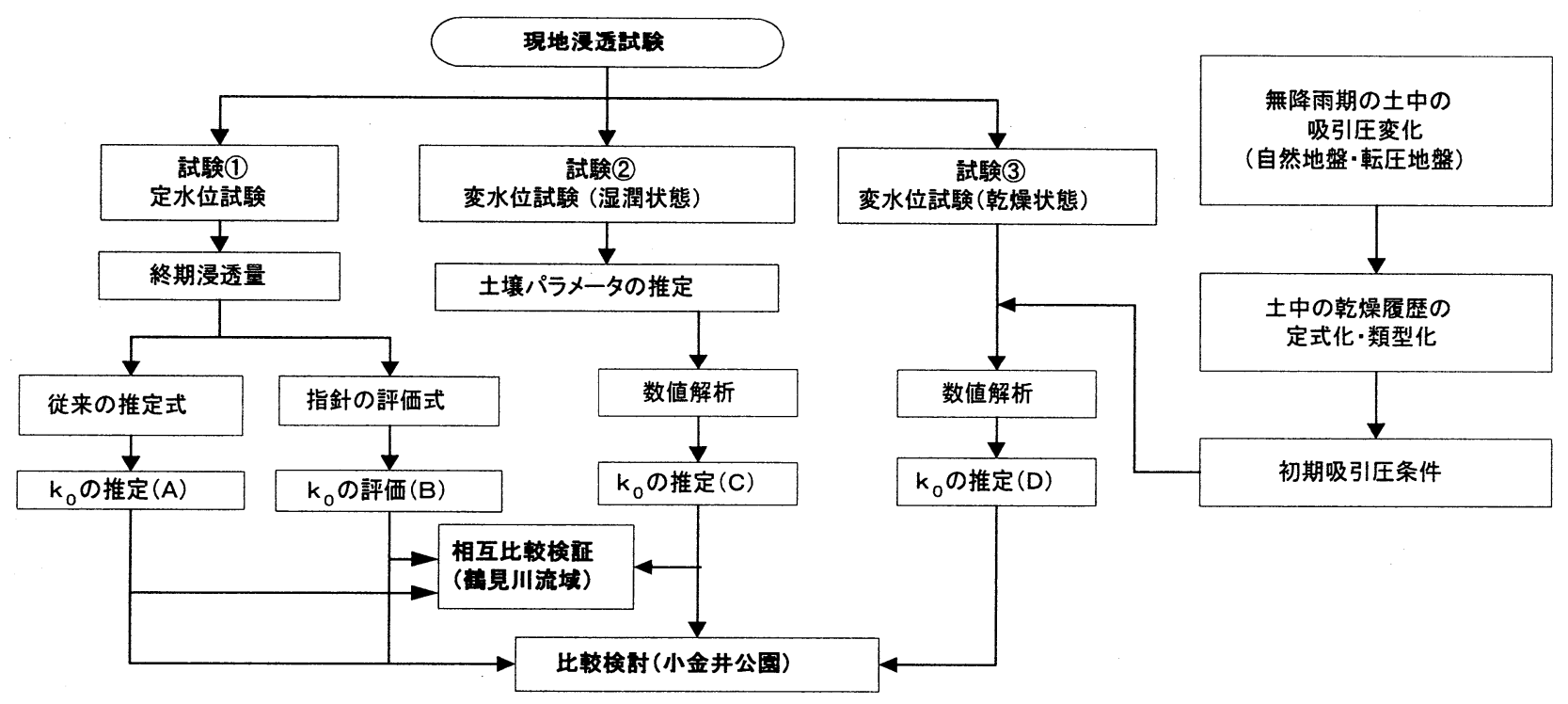

図-2 研究のフロー

ては、試験(1)での評価結果に基づいて、試験(2)の解析 を行った上で、試験(3)の評価法の可能性を検討する。

図一2に本研究のフローを示す。

\section{（1）現地浸透試験法の分類}

浸透試験は、注水方法により、定水位法と変水位法 に分類できる。定水位法では一定水媣を維持するため に、制御装置と電極棒により電磁弁を制御し、ほぼ定 常状態になるまでの浸透量の時間的変化を測定する。 変水位試験では同じボアホールにおいて定水位試験の 前後（鶴見川流域では後のみ）に行い、同じ湛水深か らの水位の時間的変化を圧力センサにより測定する。

\section{（2）従来の定水位試験の評価方法}

技術指針 ${ }^{1)}$ では、定水位試験結果から得られる試験
施設の形状と湛水深に対応した終期浸透量をもとに、 次式によって、飽和透水係数 $\mathrm{k}_{0}$ （以後は $\mathrm{k}_{0}$ と表記）を算 定することが標淮的な方法となっている。 $\mathrm{k}_{0}$ に換算して 浸透能力を評価することで、種々の条件下の現地浸透 試験結果を同一の指標で比較することができる。

$$
k_{0}=Q_{t} / K_{t}
$$

ここで、 $\mathrm{k}_{0}:$ 飽和透水係数 $(\mathrm{m} / \mathrm{s})$

$Q_{\mathrm{t}}:$ 浸透試験での終期浸透量 $\left(\mathrm{m}^{3} / \mathrm{s}\right)$

$\mathrm{K}_{\mathrm{t}}$ : 試験施設の比浸透量 $\left(\mathrm{m}^{2}\right)$ で、施設の形状 で決まる定数

一方、定水位試験の評価には試験条件に応じて従来 多くのものが提案されてきたが、そのうちの代表的な ものとして次のGlover式を挙げることができる ${ }^{2)}$ 。 


$$
k_{0}=\frac{Q_{t}}{C_{u} \cdot r \cdot h}, \quad C_{u}=\frac{2 \pi(h / r)}{\sinh ^{-1}(h / r)-1}
$$

ここで、 $\mathrm{r}$ : ボアホール半径, $\mathrm{h}$ : 湛水深 Glover式に関しては、湛水深が小さい場合は適合度に 問題があることが指摘されている ${ }^{6)}$ 。この原因の一つ として、Glover式の理論においては、(h/r)の值が減少 するにつれてボアホール底面からの浸透の割合が増大 する点が考慮されていないことが挙げられる。このよ うな問題点も含め、後述する変水位試験の数值解析の 結果と合わせて議論することとする。

\section{（3）従来の変水位試験の評価方法}

変水位試験の結果を片対数紙上にプロットすると直 線に近い関係が得られることから、この傾きを一つの 指標として整理することが多い7)。これを浸透能力係 数と呼ぶが、定水位試験結果と同一の指標で判断でき る絶対的尺度（本研究では $k_{0}$ に相当）ではないため、技 術指針では採用されていない。この指標と定水位試験 による $\mathrm{k}_{0}$ との間には密接な関係がある ${ }^{8)}$ が、検証はなさ れていない。

\section{3. 変水位試験の解析方法}

変水位試験の解析では、支配方程式としてRichards の式を用い、F E Mを用いた離散化により軸対称の浸 透現象を再現する。具体的には施設形状等の計算条件 を現地試験と同等にとり、 $\mathrm{k}_{0}$ をパラメータとして、再現 性のよい $\mathrm{k}_{0}$ の推定を行う。数值解析により変水位試験の 再現性を吟味するためには、水分保持・透水特性なら びに初期条件を決定しなければならない。筆者ら ${ }^{4)}$ は 水分保持特性 $(\theta-\phi$ 関係 $)$ としてCampbell式と Haverkamp式の 2 つを比較検討した結果、前者には解析 結果に大きな影響を及ぼしかつpF試験等による決定が 困難なパラメータが含まれており、実用上大きな障害 になることを指摘した。

これを踏まえて、 $\theta-\phi$ 関係ならびに $\mathrm{k} 一 \phi$ 関係には Haverkamp式とIrmay式を以下のように用いることとし た。

$\theta-\phi$ 関係式 : $\frac{\theta-\theta_{r}}{\theta_{0}-\theta_{r}}=\frac{\alpha}{\alpha+[\ln |\psi|]^{\beta}}$

$\mathrm{k}-\phi$ 関係式 $: k=k_{0} \cdot\left\{\frac{\alpha}{\alpha+[\ln |\psi|]^{\beta}}\right\}^{3}$

ここで、 $\theta_{0}$ : 飽和含水率, $\theta_{\mathrm{r}}$ : 残留含水率 $\alpha, \beta:$ 定数, $\phi:$ 吸引圧

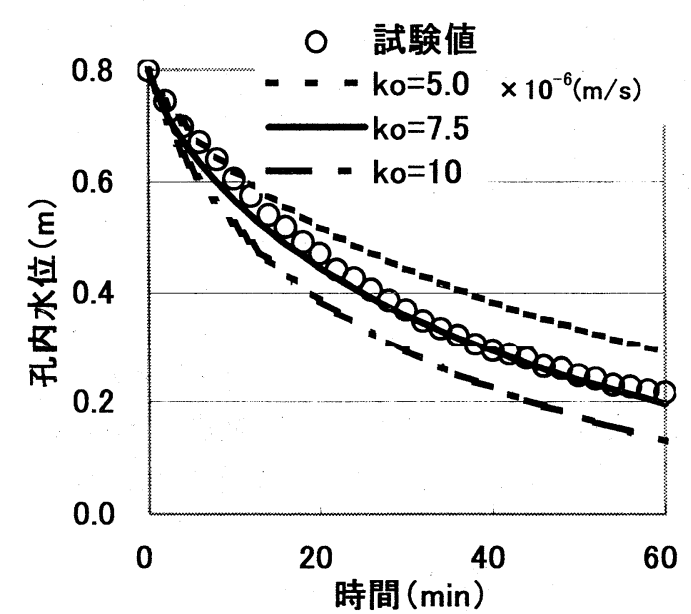

図-3 変水位試験（試験(2) による $\mathrm{k}_{0}$ の推定結果 (鶴見川流域)

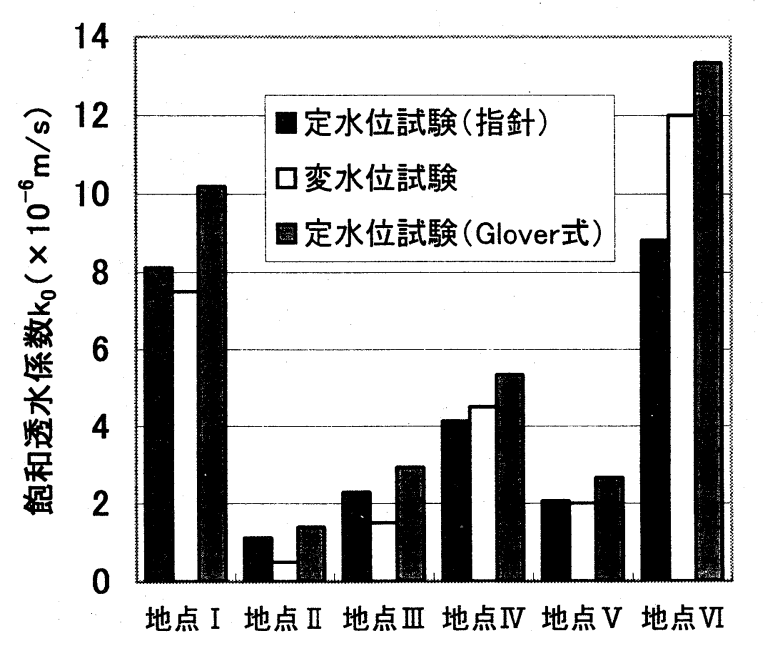

図-4 各種試験法による $\mathrm{k}_{0}$ の推定結果（鶴見川流域）

\section{4. 湿潤状態での変水位試験（試験(2)）の評価}

\section{（1）土壌パラメータの決定方法}

一般に、土壤特性は土壤の種類ごとに変化するだけ でなく、同一種類の土壌でも場所によって変化するた め、厳密には、現位置における土壤の小サンプルを用 いた室内試験（pF試験など）を行い、特性値を求めて おくことが望ましい。しかし、試験地点ごとにこのよ うな作業を行うことは実用上困難なため、土畩特性の 類型化が必要となる。

湿潤状態での変水位試験は、定水位試験終了後であ るため、ボアホール付近の土壤が飽和に近い状態であ ることを表している。ここでは、乾燥時の変水位法の 評価に先立ち、初期吸引圧分布が比較的安定している 湿潤条件を用いて土䁃パラメータをあらかじめ規定し ておくという立場をとる。小金井公園の湿潤土壌につ いて、筆者らは変水位試験（試験(2)）からパラメータ の同定を行い、表-2に示寸ような值が再現性のよい計 算条件であることを確認している ${ }^{4)}$ 。 
しかし、表-2の值はあくまで小金井公園の代表値で あり、他の関東ローム地盤への適用可能性については 十分な検討がされていない。そこでこの計算条件を用 いて、鶴見川流域の関東ローム地盤で実施された変水 位試験の $\mathrm{k}_{0}$ の推定を行うことで、土壤パラメータの整合 性を検証する。具体的には、まず、鶴見川流域で実施 された定水位試験（試験(1)）の結果から求めた終期浸 透量 $Q_{\mathrm{t}}$ をとに、(1) (2) 式から得られたそれぞれの $\mathrm{k}_{0}$ と、 定水位後の変水位試験（試験(2)）から推定した $\mathrm{k}_{0}$ の 3 者

（図-2のフローのA，B，C）の比較を行う。

\section{（2）推定したk。の比較}

試験(2)による推定結果の 1 例を図-3に示すが、この 例では $\mathrm{k}_{0}=7.5 \times 10^{-6}(\mathrm{~m} / \mathrm{s})$ 程度と推定される。これら の結果を試験地点ごとに比較したものが図-4である。

（1）式の比浸透量を用いた指針による評価方法と

（2）式のGlover式で求めた $\mathrm{k}_{0}$ を比較すると、後者によ るものが過大に評価される傾向にある。終期浸透量 $Q_{t}$ は 同一の值を用いていることから、これは算定式の違い から生じたものである。図中には示されていないが、 湛水深が低下寸るにつれて技術指針 ${ }^{11}$ による算定式と の差が増加していくことが明らかとなった。特に

$(\mathrm{H} / \mathrm{r})$ が 5 より小さくなるとその差が顕著となる。こ の結果は、2.（2）で指摘したGlover式の問題点と符合 するものであり、定水位試験の場合、指針から求めた 飽和透水係数を浸透能力の指標として用いる方が妥当 と判断される。

変水位試験（試験(2)）の $\mathrm{k}_{0}$ は全般的に過小評価の傾向 がみられる。この原因として、定水位試験後の変水位 試験であるため、浸透面の目詰まりによって孔内水位 の低減速度が遅くなったことも考えられる。事実、透 水係数が低い地点の土壌にはシルト混じりのもの（例 えば地点 II， III）もいくつかあり、試験後の目視によ る検査からも細粒分の溶出が顕著であった。また、目 詰まりによって孔内水位が低下しなくなり実験を中止 した例もあった。以上の結果から、地被条件の評価な どに問題は残るが、関東ロームという土質分類で土壌 パラメータを同定することは可能であると判断した。

\section{5. 初期条件（初期吸引圧）の推定}

現地変水位試験結果から地盤の浸透能力（飽和透水 係数 $\mathrm{k}_{0}$ ) を数值解析手法により評価するためには、現 象が非定常であるため、初期条件として対象土壤の初 期吸引圧分布をあらかじめ推定しておく必要がある。 特に定水位試験前の変水位試験（試験(3) を解析する 場合は初期吸引圧がその微小な変動でさえも解析結果 に大きな影響を及ぼすため、その設定は深度方向の分 布も含め慎重に行わなければならない。ここでは長期
表-3 各地区の土壌特性

\begin{tabular}{|c|c|c|c|}
\hline 対象地域 & 土袞特性 & 十啠分類 & $\begin{array}{l}\text { 地被 } \\
\text { 条件 }\end{array}$ \\
\hline 長池地区 & 自然地盤 & \multirow{3}{*}{ 関東ローム } & 林地 \\
\hline 永山地区 & 転圧地盤 & & 裸地 \\
\hline $\begin{array}{l}\text { 小金井 } \\
\text { 公園内 }\end{array}$ & 自然地盤 & & 裸地 \\
\hline
\end{tabular}

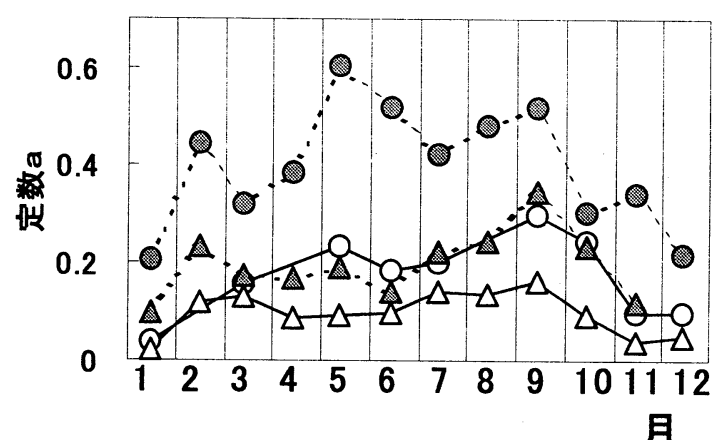

月

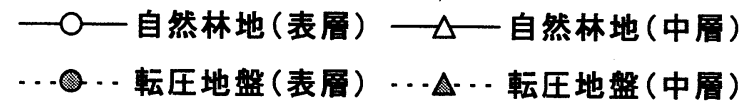

図-5 定数 $\mathrm{a}$ の季節的変化

にわたる土壇吸引圧の実測記録（テンシオメータによ る長期測定記録）を用いた土壤初期吸引圧の定式化、 およびそれに基づいた、より利便性の高い初期吸引圧 の推定手法について検討する。

テンシオメータの測定記録は 2 試験区のそれぞれタ イプの異なる土壌（自然林地、転圧地盤）であり、变 水位試験結果の解析の対象とする小金井公園を含めた それぞれの特徴は表-3に示した通りである。

\section{（1）乾燥履歴の定式化}

土壤の初期吸引圧については、多摩ニュータウン地 区でのテンシオメータを用いた土壤吸引圧の長期測定 記録から、関東ローム土畩における無降雨期の不飽和 帯吸引圧 $\phi$ の時間的変化は以下の式で近似できること が示されている ${ }^{9)}$ 。

$$
\log \left(\psi / \psi_{0}\right)=a \cdot \sqrt{t}
$$

ここに、 t は降雨終了からの経過時間、 $\phi_{0}$ は降雨終了 後 1 日程度経過した状態の吸引圧で最小容水量に相当 する。また、定数 $\mathrm{a}$ は降雨終了後の経過日数による吸 引圧の増加割合を表し、季節的要因に支配されると考 えられる。

\section{（2）推定式のパラメータの類型化}

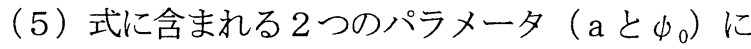
はばらつきはあるものの、季節的には明確な特徵がみ 


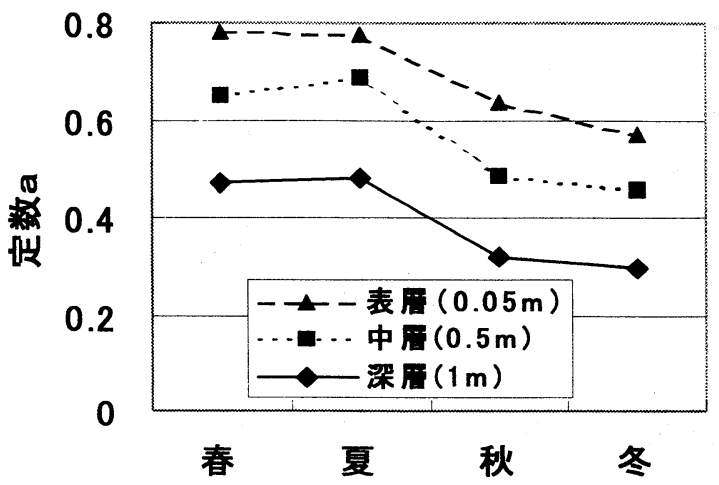

図-6 自然林地の各深度における定数 a の変動傾向

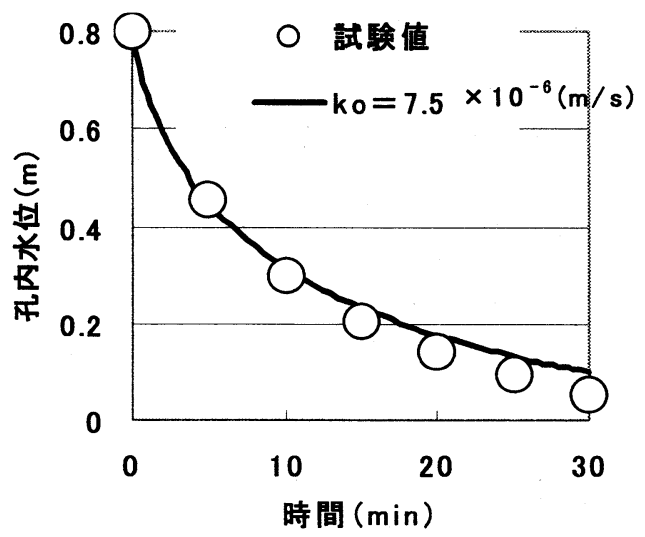

図-7 変水位試験（試験(3)）による $\mathrm{k}_{0}$ の推定結果 (小金井公園)

られる。しかし、岡ら ${ }^{4)}$ ではこれらのパラメータの適 用方法にやや問題があり、初期吸引圧条件の設定が不 十分なものであった。本研究ではその点を踏まえ、土 壌の特徽等を考慮し、各パラメータの変動傾向の定量 的な把握方法について検討する。

\section{a）季節的な変動傾向}

定数 $\mathrm{a}$ は降雨後の経過日数による吸引圧值の増加割 合を表しており、季節的な気象要因および地被条件に 支配されると考えられる。図一5に、自然林地と転圧地

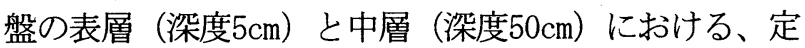
数 $\mathrm{a}$ の季節的な変化を示す。個々のデータにばらつき があるため、月単位で平均してある。全般的な傾向と して定数 a は冬期に小さく、春になると漸増傾向を示 し、8〜9月の夏期にピークを示す。10月以降は急速 に減少する傾向を見せている。以上のことから、定数 a の分布は季節ごとに特徵的な傾向を示しており、こ うした傾向を考慮に入れた上で類型化することができ ると考えられる。

\section{b) 各土壤の同一深度での比較}

図一5から、さらに、同一深度（表層）における2 種 類の土袞で定数 $\mathrm{a}$ の変動傾向を比較すると、すべての 媣度において自然林地よりも転圧地盤の值が大きい。 これは両者の地被条件の相違に起因する。

\section{c）同一土壤における分布傾向}

自然林地土㙵での 3 深度（表層 : $5 \mathrm{~cm}$ 、中層 : $50 \mathrm{~cm}$ 、 深層：100cm）における定数 a の変動傾向を図-6に示 す。地表面付近の值は大きく、中層、深層と深くなる につれて小さくなっている。

以上の結果を踏まえて、（5)式のパラメータ a を季 節ごとに統合し、さらにそれを深度別に分類する方法 で初期吸引圧の定量化を行った。一方、観測記録によ れば、もう 1 つパラメータ $\phi_{0} に$ 若干の変動は見られ るが、自然林地土畩では最小容水量の範囲内 $(\mathrm{pF} 1.7$ 2.0）にあるごとから、先ほどの分類法との整合性を考 慮して、季節ならびに深度ごとの類型化を行った。

\section{（3）初期条件の分布}

前項（2）で整理したパラメータを用いた推定式 （(5)式）を用いて、3 3 深度（表層: $5 \mathrm{~cm}$ 、中層 : $50 \mathrm{~cm}$ 、 深層 : $100 \mathrm{~cm})$ ごとに初期吸引圧を算出した。この值に 基づいて、現地試験の土壌における吸引圧分布を的確 に表現できるようにした。具体的には、地表面から深 度 $50 \mathrm{~cm}$ までは深度 $5 \mathrm{~cm}$ と $50 \mathrm{~cm}$ の吸引圧 (pF値) で直線的

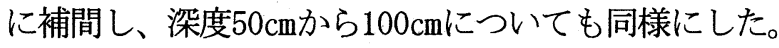
また、深度 $100 \mathrm{~cm}$ 以深の吸引圧はごく小さな範囲内でし か変化しないことから、深度 $100 \mathrm{~cm}$ 以深では深度 $100 \mathrm{~cm}$ の值を一様に分布させた。

\section{6. 乾燥状態での变水位試験（試験(3)）の評価}

類型化したパラメータ（定数 a ならびに $\phi_{0}$ ）を基に 初期吸引圧条件を設定する手法を用いて、小金井公園 で行われた定水位前の変水位試験（試験(3)）の解析を 行った。解析で必要となる土壌パラメータとしては4. で評価の妥当性が検証されている表-3の值を用いた。

次に、ほぼ同じ気象条件であれば、（5）式の定数 a には地被条件がもっとも大きな影響を与えることを 考慮し、裸地地盤である小金井公園の a の值として、 転圧地般（永山地区）のものを用いる。ととする。

一方、 $\varphi_{0}$ は最小容水量範囲 $(\mathrm{pF} 1.7 \sim 2.0)$ に相当寸 るものであるが、試験地点は自然地盤であり、透水性 の比較的よい土㙵であることから、自然林地（長池地 区）の值を用いることとした。解析結果の 1 例を図-7 に示す。実験值と比較すると乾燥時の変水位試験（試 験(3)）の飽和透水係数 $\mathrm{k}_{0}$ は $7.5 \times 10^{-6} \mathrm{~m} / \mathrm{s}$ 程度であると推 定できる。以上のような方法で試験地点ごとに解析を 行い、定水位試験（試験(1) ならびに湿潤時の変水位 試験（試験(2) から得られた結果と比較したものが図8である。

乾燥時の変水位試験（試験(3）結果から推定した $\mathrm{k}_{0}$ は 全体的にみて定水位試験の值（指針）よりもやや大き めとなっている傾向が特に夏期に見られる。この原因 


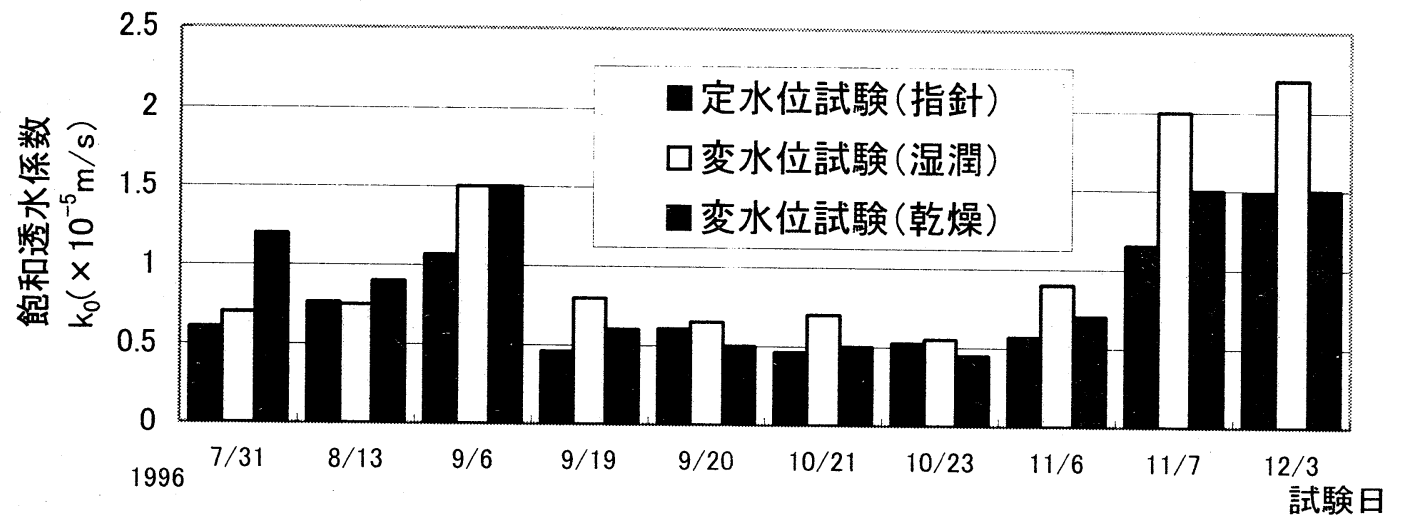

図-8 各種試験法による $\mathrm{k}_{0}$ の算定結果（小金井公園）

としては、試験実施地点での初期条件が実際の值より も湿潤な状態に設定されている可能性が考えられる。 このような差異はあるものの、透水係数の大小にかか わらず、3者はほぼ見合う值となっており、本研究で 提示した評価方法の妥当性が確認できたと考えられる。

また、この解析を通じて、定数 a および $\psi_{0}$ の定式化 および類型化を図るための基礎データを得た自然地盤

（長池）と転圧地盤（永山）とは異なる土壌タイプの 小金井公園にも推定式の適用範囲を広げることが可能 なこと、さらに、2つのパラメータ（定数a、 $\phi_{0}$ ) の それぞれの特性をある程度明らかにすることができた。

\section{7. まとめ}

本研究では、関東ローム地盤において実施した定水 位ならびに変水位の現地ボアホール試験に基づき、乾 燥条件下での変水位試験による浸透能力評価手法につ いて検討を行った。得られた成果は以下のとおりであ る。

（1）鶴見川流域での試験・解析結果より、関東ロー ムにかかわる標準的な土壌パラメータの妥当性を検証 した。

（2）変水位試験の評価方法のうち、従来多用されて きたGlover式の問題点を具体的に明らかにした。

（3）テンシオメータを用いた、長期の現地不飽和带 吸引圧観測値から得られた経験式を基に、土壌特性の 異なる地区の深度別および季節別の乾燥履歷を定量化 し、土壤の初期吸引圧条件の規定方法を整理した。

（4）この条件を用いた小金井公園の試験結果の解析 により乾燥時の変水位透水試験結果から飽和透水係数 を推定し、定水位推定法および湿潤時の変水位試験結 果との比較を行い、比較的よい評価精度が確認できた。

以上により、本研究で提示した変水位試験の評価手 法の妥当性がある程度検証できたと考えられるが、一 般化するにはまだ多くの課題が残されている。今回、
関東ロームを対象としたが、その他の土袞については 浸透試験データのみならず初期条件にかかわるデータ も不足しており、同レベルの議論にいたっていないの が現状である。また、乾燥時の変水位試験実施方法の 見直しも必要と考えている。すなわち、試験回数、一 般化しやすい試験条件など、実用化に向けて更に検討 を要する。

\section{参考文献}

1）雨水貯留浸透技術協会編: 雨水浸透施設技術指針（案）調 查・計画編, 1995.

2) Stephens, D. B. and Neuman, S.P. : Vadose Zone Permeability Tests, Summary, Journal of Hydraulic Division, ASCE, No. 108, pp.623-639, 1982.

3) 西垣誠: 地盤の浸透特性と浸透能力, 雨水技術資料, Vol. 14, pp. 9-20, 1994.

4) 岡泰道, 岩城孝之, 井上昇 : 変水位ボアホール浸透試験に 基づく現地地盤の浸透能力の評価手法に関する研究, 水工 学論文集, 第41巻, pp. 13-18, 1997.

5）吉沢拓也, 齋藤庸 : 現地浸透実験法の簡略法に関する検討 一簡易浸透実験法の提案一， 日本工営技術情報，№. 19， pp. 119-126, 1998.

6) 岡泰道, 今井素生, 井上昇, 羽田誠 : 現地ボアホール浸透 試験結果の評価方法の検討, 水文・水資源学会1995年研究 発表会要旨集, pp. 44-45, 1995.

7) 北海道開発コンサルタント(㑣): 浸透施設の機構と流出抑制 効果に関する研究，技術開発部研究論文，HR-006， 1984.

8) グエン・ソン・フン : 雨水浸透施設における表層地盤の浸 透能力係数と飽和透水倸数との関倸について, 雨水技術資 料, Vol. 32, pp. 117-119, 1999.

9）虫明功臣, 岡泰道, 小池雅洋: 自然林地における表層不飽 和帯水分の挙動に関する研究 (2) , 第29回水理講演会論文 集, pp. 131-136, 1985.

(2000.10.2受付) 